\title{
A PROPÓSITO DA AÇÃO DE ALGUMAS DROGAS SÔBRE A GERMINAÇÃO DE SEMENTES
}

(TO THE PURPOSE OF THE ACTION OF SOME DRUGS OVER THE SEEDS' GERMINATION)

\section{Prestes Monzoni Lais Helena Paiva Azevedo}

A natureza vegetal das bactérias conduziu os pesquisadores ao estudo do efeito das substâncias bacteriostáticas sôbre a germinação de sementes. Assim é que FonseCA Ribeiro (1) trabalhou com a sulfanilamida no processo da germinação das sementes de arroz, provando sua atividade e verificando a manutenção do antagonismo do ácido para-aminobenzóico em face da droga. Posteriormente o mesmo autor (2) utilizou a penicilina em provas com sementes de alface, sendo os resultados confirmados e completados por SMITH ${ }^{(3)}$.

Trabalhando na mesma ordem de pesquisas, escolhemos outras substâncias ativas sôbre microorganismos, a fim de verificar seu comportamento durante o processo de germinação de algumas espécies de sementes; para isso utilizamos o aldeído fórmico, propionato de cálcio, éster etílico do ácido para-hidroxibenzóico (nipagina) e bicloreto de mercúrio; as sementes preferidas foram as de alface (Lactuca sativa L.), couve (Brassica oleraccae L. fórma acéfala), rabanete (Raphanus sativus L.) e repolho (Brassica oleraceae L. forma capitata).

As sementes eram colocadas, sempre em número de quarenta, em béquers de $100 \mathrm{~cm}^{3}$ de capacidade, contendo $20 \mathrm{~cm}^{3}$ das soluções das drogas diluídas a $1: 100,1: 1.000,1: 10.000$ e $1: 100.000$. Apenas para o éster do ácido para-hidroxibenzóico não foi feita a primeira diluição, em virtude da pouca solubilidade. Como testemunha, usamos simplesmente água e as leituras foram feitas cada 24 horas, durante seis dias.

O quadro seguinte mostra os resultados, com relação ao número de sementes germinadas e o comprimento médio das raízes.

Verifica-se dêste quadro que para tôdas as espécies de sementes experimentadas o aldeído fórmico foi inibidor até na diluição de 1:100.000, como o foi também o bicloreto de mercúrio, embora para esta droga não houvesse limitação do número de sementes germinadas de rabanete, sendo não obstante prejudicado o crescimento $(0,5-2,5 \mathrm{~cm}$ em relação $1.5-5 \mathrm{~cm}$ des testemunhes!; para a nipagina foram mais 
Q U A D R O I

Ação de algumas drogas sôbre a germinação de sementes

\begin{tabular}{|c|c|c|c|c|c|c|c|c|c|c|c|c|c|c|c|c|c|}
\hline \multirow{4}{*}{$\begin{array}{l}\overrightarrow{30} \\
\stackrel{0}{0}\end{array}$} & \multirow{4}{*}{ Diluị̧āo } & \multicolumn{4}{|c|}{ Alface } & \multicolumn{4}{|c|}{ Rabanete } & \multicolumn{4}{|c|}{ Couve } & \multicolumn{4}{|c|}{ Repolho } \\
\hline & & \multirow{2}{*}{\multicolumn{3}{|c|}{$\begin{array}{c}\begin{array}{c}\text { No de sementes } \\
\text { germinadas }\end{array} \\
\text { Dias }\end{array}$}} & \multirow{3}{*}{$\begin{array}{c}\text { Compri- } \\
\text { mento } \\
\text { das } \\
\text { raizcs } \\
\mathrm{cm}\end{array}$} & \multirow{2}{*}{\multicolumn{3}{|c|}{$\begin{array}{c}\begin{array}{c}\text { Nin de scmentes } \\
\text { Berminadas }\end{array} \\
\text { Dias } \\
\end{array}$}} & \multirow{3}{*}{$\begin{array}{c}\text { Compri- } \\
\text { mento } \\
\text { dias } \\
\text { ralzes } \\
\text { cmi }\end{array}$} & \multirow{2}{*}{\multicolumn{3}{|c|}{$\begin{array}{c}\begin{array}{c}\text { No de sementes } \\
\text { germinadas }\end{array} \\
\text { Dias }\end{array}$}} & \multirow{3}{*}{$\begin{array}{c}\text { compin- } \\
\text { mento } \\
\text { dias } \\
\text { ralans } \\
\text { cml }\end{array}$} & \multicolumn{3}{|c|}{$\begin{array}{c}\text { N. de sementes } \\
\text { germinadas }\end{array}$} & \multirow{3}{*}{$\begin{array}{c}\text { Comprl- } \\
\text { mento } \\
\text { das } \\
\text { raizes } \\
c \mathrm{DI}\end{array}$} \\
\hline & & & & & & & & & & & & & & & Dias & & \\
\hline & & 2 & 1 & 6 & & 2 & 4 & 6 & & 2 & 4 & 6 & & 2 & 4 & 6 & \\
\hline fgua & 1 & 5 & 37 & 37 & $2,5-3$ & 11 & 39 & 39 & $4,5-5$ & 5 & 21 & 32 & $5-6$ & 1 & 38 & 38 & $3-7$ \\
\hline \multirow{4}{*}{$\overbrace{\substack{c \\
c}}^{\bar{c}}$} & $1: 100$ & 0 & 0 & 0 & - & 0 & 0 & 0 & - & " & 0 & 1) & $\cdots$ & 0 & 0 & 0 & - \\
\hline & $1: 1.000$ & 0 & 0 & o & - & 0 & 0 & 0 & - & 0 & 0 & 0 & - & 0 & 0 & 0 & - \\
\hline & $1: 10.000$ & 1 & 5 & 15 & 0,5 & 2 & 10 & 26 & $0,5-0,8$ & 2 & 7 & 8 & $0,3-0,7$ & 3 & 16 & 16 & $0,3-0,5$ \\
\hline & $1: 100.000$ & 2 & 5 & 38 & $1-1,5$ & 19 & 26 & 31 & $1,5-2$ & 1 & 13 & 19 & $1-3$ & 11 & 20 & 21 & $1-1,5$ \\
\hline \multirow{4}{*}{$\frac{c}{\frac{a}{n g}}$} & $1: 100$ & 0 & 0 & 0 & - & n & 0 & 0 & - & 0 & 0 & 0 & - & 0 & 0 & 0 & - \\
\hline & $1: 1.000$ & 0 & 0 & 0 & $0,5-0,8$ & 0 & 0) & 1 & - & ì & 0 & 0 & - & 2 & 11 & 11 & $0,3-0,5$ \\
\hline & $1: 10.000$ & 3 & 14 & $3 \overline{5}$ & 1,5 & 4 & 12 & 12 & $1-1,8$ & 0 & 8 & 13 & $0,3-0,5$ & 10 & 19 & 21 & $1-4$ \\
\hline & $1: 100.000$ & 2 & 1.3 & 10 & $2,5-3$ & 16 & 31 & 31 & 2,53 & 2 & 6 & 7 & $4-5$ & 13 & 20 & 21 & $4-5$ \\
\hline \multirow{4}{*}{ 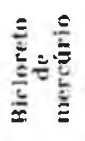 } & $1: 100$ & 0 & 0 & 0 & - & 0 & 0 & 0 & - & 0 & ॥ & 0 & - & 0 & 0 & 0 & - \\
\hline & $1: 1.000$ & 0 & 0 & 0 & - & 0 & 0 & 0 & - & n & 0 & 0 & - & 0 & 0 & 0 & - \\
\hline & 1:10.000 & $n$ & 0 & 0 & - & 1 & 3 & 5 & 0,2 & 2 & 2 & 2 & $0,3-0,5$ & 4 & 8 & 8 & $0,3-0,6$ \\
\hline & $1: 100.000$ & 0 & 0 & 7 & 0,3 & 25 & 25 & 39 & $0,5-2,5$ & 1 & 12 & 17 & $1-2.5$ & 1.1 & 27 & 27 & $2-3$ \\
\hline \multirow{3}{*}{$\frac{\bar{E}}{\bar{x}}$} & $1: 1.000$ & 0 & 0 & $n$ & - & 0 & 0 & 0 & - & 0 & n & 0 & - & 0 & 0 & 0 & - \\
\hline & $1: 10.000$ & 1 & 9 & 9 & 1,2 & 7 & 10 & 13 & $0,5-2$ & 1 & 2 & 2 & 1 & 8 & 22 & 29 & 1 \\
\hline & $1: 100.000$ & 2 & 12 & 40 & $1,5-3$ & 19 & 27 & 34 & $4-5$ & 4 & 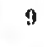 & 13 & $2-5$ & 8 & 18 & 18 & $1-3$ \\
\hline
\end{tabular}


sensiveis as sementes de couve e de repolho e para o propionato de cálcio a ação inibidora não foi além da diluição de $1: 10.000$.

Com o fim de verificar se o efeito manifestado pelas drogas seria de tipo definitivo ou de características fitostáticas, realizamos uma segunda experimentação; depois de colocadas em presença da droga, durante 48 horas, as sementes eram lavadas e deixadas em água. Os resultados foram os seguintes:

$$
\text { QU A I) R O II }
$$

Germinaçă de sementes após 48 horas de contacto com substâncias impedientes da germinação

\begin{tabular}{|c|c|c|c|c|c|c|c|c|c|}
\hline \multirow[b]{2}{*}{ I) roga } & \multirow[b]{2}{*}{ Diluiçĩon } & \multicolumn{2}{|c|}{ Alface } & \multicolumn{2}{|c|}{ - Rabanete } & \multicolumn{2}{|c|}{ Couve } & \multicolumn{2}{|c|}{ Repolho } \\
\hline & & 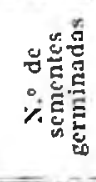 & 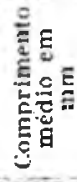 & 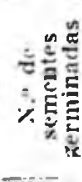 & 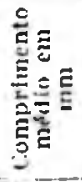 & 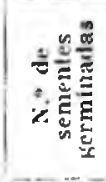 & 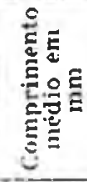 & 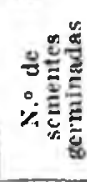 & 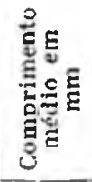 \\
\hline A מ̆lu & 1 & 37 & 20 & 39 & 20 & 14 & 6 & 18 & 18 \\
\hline & $1: 100)$ & $n$ & 0 & 0 & 0 & 1) & 0 & 0 & 0 \\
\hline$\underline{\underline{E}}$ & $1: 1.0001$ & 2 & 20 & 0 & 0 & 0 & 0 & 0 & 0 \\
\hline 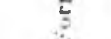 & $1: 10.000$ & 26 & 11 & 34 & 10 & 8 & 10 & 8 & 7 \\
\hline$\therefore$ & $1: 100.0100$ & 16 & 18 & 36 & 13 & fi & 6 & 14 & 12 \\
\hline$\stackrel{2}{=}$ & $1: 100$ & 21 & $x$ & 4 & 2 & $\neq$ & 8 & 22 & 12 \\
\hline$\ddot{z}$ & $1: 1.010$ & 29 & $x$ & 31 & 12 & 21 & 10 & 30 & 10 \\
\hline $\bar{c} \frac{\pi}{\pi}$ & $1: 10.000$ & 28 & 10 & 40 & 15 & 2 & 5 & 12 & 5 \\
\hline$\stackrel{5}{\underline{\Delta}}$ & $1: 100.000$ & 30 & 11 & 36 & 21) & 1 & 5 & 12 & 12 \\
\hline & $-\quad-$ & & & & & & & & \\
\hline$\subseteq \cong$ & $1: 100$ & $n$ & 0 & 0 & 0 & 0 & 0 & 0 & 0 \\
\hline 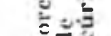 & $1: 1.000$ & 0 & n & 0 & 0 & 0 & 0 & 0 & 0 \\
\hline$\Xi=$ & $1: 10.000$ & 0 & 211 & 10 & 2 & 2 & 2 & 12 & 5 \\
\hline$\ddot{\oplus} \check{E}$ & $1: 100.000$ & 10 & 11 & 36 & 12 & 4 & 5 & 16 & 6 \\
\hline I & $1: 1.0000$ & 1 & 8 & 20 & 10 & 0 & 0 & 4 & 2 \\
\hline$\vec{x}$ & $1: 10.000$ & 20 & 8 & 36 & 10 & 6 & 2. & 6 & 3 \\
\hline$\frac{\bar{z}}{\%}$ & $1: 100.0100$ & 24 & 6 & 40 & $1 \overline{1}$ & 6 & 1 & 10 & 7 \\
\hline
\end{tabular}

A inspeção dêste quadro permite concluir que das substâncias de provas, o propionato de cálcio e a nipagina, sendo as menos ativas na inibição da germinação das sementes, são também as que menos lesam o embrião. Para o bicloreto de mercúrio e o formol, o efeito inibidor é indelével até nas concentração de 1:1.000 e, acima destas, varia de acôrdo com a espécie de semente utilizada. 


\section{RESUMO}

Os autores estudaram a ação de substâncias já reconhecidas como bactericidas ou bacteriostáticas, sôbre a germinação de algumas espécies de sementes: Alface (Lactuca sativa L.) ; Repolho (Brassica oleraceae L. fórma capitata); Rabanete (Raphanus sativus L.); Couve (Brassica oleraceae L. forma acéfala). Verificaram que nas concentraçōes de 1:100, 1:1.000, 1:10.000 e 1:100.000, o formol e o bicloreto de mercúrio têm ação inibidora sôbre as citadas sementes. As drogas atuam sôbre o embrião determinando a incapacidade germinativa; no que diz respeito ao propionato de cálcio e nipagina (éster etílico do ácido para-hidroxibenzóico), a ação inibidora é uma conseqüência da presença dessas substâncias. As sementes depois de 48 horas de contacto com êstes compostos foram lavadas em água e mostraram-se aptas à germinação.

\section{SUMMARY}

The AA. studied the action of substances already known as bactericide or bacteriostatic over germination of some kinds of seeds: lettuce (Lactuca sativa L.); cabage (Brassica oleraceae capitata form); radish (Raphanus sativus L.); green kale ( $B$ rassica o leracea acephalous form). They found that in concentrations such as $1: 100,1: 1,000,1: 10,000$ and $1: 100,000$, the formaldehyde and the mercuric cloride have inhibited action over the seeds mentioned before. The drugs act over the embryo determining the breeding incapacity; regarding the calcium propionate and nipagin (etilic ester of para-hidroxibenzoic acid) the inhibited action is a consequence of the presence of such substances. The seeds after 48 hours of contact with these agents were washed in water and showed themselves capables of breeding.

\section{REFERENCIAS BIBLIOGRAFICAS}

1 -- Fonseca Ribeiro, D. - 1944 - Influence of sulfanilamide on the germination of seeds. J. Biol. Chem., 152 (3) : 665-7

2 - FonsfCA Ribiriro), D. - 1946 - Penicillin action on the germination of seeds. Science, $104(2688): 18$

3 - Sмith, J. W. - 1946 - Effect of penicillin on seed germination. Science, 101 $(2705): 411-413$ 